\title{
Educating capitalists: a rejoinder to Wright and Tsakalotos
}

\section{Wolfgang Streeck}

Max Planck Institute for the Study of Societies, Cologne

Correspondence: streeck@mpifg.de

The paper takes up the basic issue, addressed by both commentators, of whether one can speak of economic performance as a general interest superseding the special interests of groups or classes. It suggests a dynamic concept of capitalist class interests that allows for a contingent, precarious, and perhaps increasingly less feasible reconciliation between general and special interests in economic performance

Keywords: Institutions, interests, preferences, equity and efficiency, functionalism

JEL Classification: P16 - Political Economy

My article, 'Beneficial Constraints: On the Economic Limits of Rational Voluntarism' (Streeck, 1997), written in 1993 and published four years later, deals with a fundamental question of socio-economics: can, should, must societies reorganize their politics and their social institutions for the purpose of better economic performance? In two impressively argued comments, Erik Wright and Euclid Tsakalotos, while they agree on the importance of the subject, take issue both with the way I am asking the question and with the answer that I offer. In some respects, by no means minor ones, I read their comments as friendly amendments that I can happily take on board. In others, however, they challenge major underlying assumptions of my argument, and to advance our discussion my response will deal almost exclusively with this part of their essays. I begin with a brief reconstruction of my central point, for brevity's sake in slightly different terms. Then, I will take up the basic issue, addressed by both commentators, of whether and in what sense one can speak of economic performance as a general interest superseding the particularistic interests of groups or classes. Finally, I shall suggest a dynamic concept of economic interests, in particular capitalist class interests, that allows for 
a politically contingent, precarious, and perhaps increasingly less feasible reconciliation between general and special interests in economic performance.

\section{I}

Can, should, must societies be rationalized in order to make them more economically efficient? Today, in a period of accelerating competitive 'globalization' and in the face of the economistic rhetoric of neo-liberalism that accompanies it, the relevance of this question is more obvious than ever. My answer in the article amounted in its core to a rejection of economic functionalism in political-institutional analysis, of the sort that prevails in much of the current political-economy literature, and in particular in the more recent literature on 'varieties of capitalism'. Theories of political economy, I argued, and generally theories of economy-in-society, should rid themselves of functionalist assumptions, in particular those premised on 'rational-choice'-type 'micro-foundations' that implicitly or explicitly endow actors, or at least some of them, with vastly exaggerated cognitive and political capacities for purposive institutional design. To demonstrate this I offered an attempt to make sense of a frequent but theoretically under-exploited empirical observation: namely that institutions, policies, traditions etc. that were clearly not created for economic reasons and with economic efficiency in mind, may turn out to be sources of superior economic performance and competitiveness. Indeed empirical evidence suggests that this may apply even to social arrangements that were initially, or continue to be, perceived and resisted by economic actors, in particular but not exclusively capitalists, as irrational constraints on the pursuit of economic improvement in general and on the operation of free markets in particular. Examples include unemployment benefit, a high minimum wage, employment protection, trade unions, legal institutions of workplace participation, public regulation of workplace-based training, but also environmental regulations and informal codes of how to do business in particular industries or regions.

How may constraints on economic activities be turned into sources of economic opportunity? A more concrete version of this question would be how it is that capitalists should be found to benefit from and perhaps eventually support social institutions that they have originally condemned as costly limitations on, in the term I use in the article, their 'rational voluntarism. ${ }^{1}$ There are several more or less satisfactory types of answers to this. The currently preferred one would draw on rationalistic foundational narratives of the Leviathan or Ulysses-and-the-sirens or prisoners' dilemma type. In them individually rational actors somehow manage rationally to recognize the limits of rational individualism and agree to do what they fundamentally hate to do: tie their own hands by submitting to a supreme 
ruler, or a binding rule, so as to ensure that each coordinates his or her action with all others to the benefit of all. I did not follow this path in the article and will not do so here, since I believe that the telling of stylized fiction of this sort, in addition to all the other problems it entails, attributes far too much foresight and far too little passion to human actors and thereby, rather than solving the problem it is meant to address, only defines it away.

In the article, then, I offer two different answers, one more conventional and the other, I believe, more original, both avoiding the functionalist fallacies of fictitious rational-choice mythology in favour of focusing on empirically observable social relationships and processes. The more conventional, I could also say more sociological, answer emphasizes the contribution of normative integration to the smooth operation of social systems, including economic ones. Social justice, as embodied for examples in non-marketable civil, political and social rights, enhances what industrial sociologists used to call 'morale' and thereby, through a complex capillary system of causal connections, may make for higher productivity. Especially in advanced production systems, an important condition of the institutions that govern the employment relationship being efficient is that employees regard them as fair. Work flows better, errors are more easily detected and corrected, improvements are introduced more frequently and spontaneously, and conflicts are more easily settled in a general 'climate' of goodwill, with the help of the many miraculous, intangible, hard-to-nail-down and yet so essential qualities that characterize an organization or, for that matter, a society with what Harvey Leibenstein (1987) has called 'X-efficiency'. Justice, I argued in the article, is more likely to be perceived as such if it is introduced, not as a means to some other end, such as efficiency, but for its own sake and as an end in itself. Then, and especially then, it may as an unanticipated side-effect increase economic productivity at a rate that more than

\footnotetext{
${ }^{1}$ Still more pointedly, neo-liberals are fond of asking why capitalists, if a given institutional constraint on economic action was really as beneficial as observers claim it was, do not observe it voluntarily, or lobby for it to be legally instituted (instead of leaving this to their opposition). Where questions of this sort are asked rhetorically, for example to discredit mandatory workplace participation, they carry two implications: (1) that capitalists are by their social nature interested in maximizing economic performance, and (2) that therefore rules that must be forced upon them cannot possibly enhance the latter. With the first implication Wright and Tsakalotos squarely disagree, whereas I treat the matter as an empirical question. On the second one Wright and Tsakalotos agree and disagree at the same time: while they recognize the possibility of economic improvement deriving from restraining capitalists, they believe that beyond a certain point capitalists cannot accept performance-enhancing constraints as this would undermine their class power. Capitalists, in other words, are willing to sacrifice economic performance to preserve the political status quo. The underlying concept seems to resemble that of the relations of production as fetters on the development of the forces of production. While I tend to agree here, I will further down suggest a more contingent relationship.
} 
compensates for the economic costs, if any, of a pluralism of social values that reduces economic performance to one value among others with which it must share pride of place.

The other, perhaps less familiar and therefore probably more interesting, mechanism by which social constraints may be turned into economic opportunities operates, not through legitimacy, but through innovation. If the logic of the former may be broadly termed Weberian, that of the latter could be labelled Schumpeterian. It takes for granted that economic action, entrepreneurship and capitalism are embedded in a constraining social context that does not, and for very basic reasons cannot, follow the dictates of competitive markets and rationalizing hierarchies. Capitalist entrepreneurs must live in and with a world in which other social actors create institutions that stand in the way of a wide range of promising strategic choices for profit-making businesses. However, faced with irremovable restrictions on their strategic repertoires, entrepreneurs can and do make use of their defining capacity, their creativity, to come to terms with and even benefit from them. Capitalists, in other words, are virtuosos, not of designing and implementing coherent economic systems, but of making do with given means under the pressure of time and circumstances, improving new solutions where old ones no longer work, discovering new possibilities, flexibly adjusting to changing conditions, and generally making a virtue out of a host of contingent necessities. Almost by definition, I claim, a capitalist entrepreneur is someone with an extraordinary ability to discover new opportunities for profit making where others perceive only constraints. To me, turning constraints into opportunities seems the very essence of entrepreneurship, and is precisely what the market rewards, and indeed should reward.

I maintain that conceiving of economic action as an intelligent accommodation of historically contingent but for the time being irremovable social constraints yields a much more realistic image of the operation of an economy than does a stylized functionalist reconstruction of social arrangements as means to the end of improving economic efficiency. Consider, for example, the case of skill formation. (More examples are offered in my article.) What skills are formed in a society and how they are distributed in its workforce reflects not just, and perhaps least, a given structure of demand in the labour market. To a large extent the supply of skills is a product of cultural traditions and aspirations, of a historically grown status structure, of prevailing concepts of social justice and legitimate stratification, and not least of the distribution of power in the polity and at the workplace. In a country like Germany, these and other factors came together in the founding decades of the late nineteenth century to produce a training regime that generated an excess supply of intermediate work skills for which modern mass production had no real use. Indeed as the twentieth century progressed German employers found themselves constrained to rely on, pay for and actually train broadly skilled 
workers that in other countries at the time were being replaced with unskilled labourers. Among the causal factors that brought this about was, as Jim Mosher has demonstrated (Mosher, 2001), a compressed wage structure combined with stable employment, both vigorously enforced by a strong industrial trade union movement. However, rather than breaking down under the cost burden of high wages and training expenses, German employers convinced themselves that, while German society refused to deliver them a skill structure suitable for rigorous Taylorist rationalization of the German production system, its stubborn insistence on a 'premodern' pattern of skill formation offered extraordinary opportunities for smallbatch production of high-quality goods, quality- rather than price-competitive, for both investment and consumption. As more and more firms discovered this, by experimentation or observation, 'typically German' business strategies spread that turned a culturally and politically given structure of the labour supply into a comparative advantage. By the 1970s and 1980s, a period that was to be particularly difficult for mass producers, these strategies had built the by far most diversified export economy in the world, with more small and medium-sized high-performance firms than any other country, with an unmatched capacity for incremental innovation and an apparently endless ability to discover, create and occupy niches in the world market that were protected from price competition. ${ }^{2}$

Allowing for the possibility of entrepreneurship creatively turning social constraints into economic opportunities spares one the embarrassment of having to define away the frequent empirical observation of business having vigorously opposed institutions that later became pillars of competitive advantage (Höpner, 2003, pp. 218-22). Unlike economic functionalism, it also makes dispensable the assumption of an omnipotent system designer somewhere behind the scenes, with advance knowledge of how, say, high wages, high skills and workplace democracy may in the end be profitably reconciled with capitalist accumulation. Instead it introduces in the analysis the possibility of capitalists learning from experience and thereby redefining, if not their interests, then their preferences (Hall, 2003). More

\footnotetext{
${ }^{2}$ Note the time specificity of this relationship. Whether a given constraint may be beneficial depends, not just on the inventiveness of the entrepreneurs that have to live with it, but also on markets ready to absorb the products on which firms under the constraint may have comparative advantage. The analysis is complicated by the fact that the existence of such markets is by definition uncertain. If and in what way a socio-economic task environment is potentially profitable for firms operating under specific constraints is at least as much a matter of practical discovery, and even 'construction' through ingenious 'marketing', as of theoretical prediction. Typically theory tends to be more conservative than practice, often declaring a priori impossible what it later has to come to terms with as empirical fact. Moreover, the sum of the constraints in a society must not be such that it completely forecloses all 'wiggling space' for entrepreneurial opportunism is foreclosed.
} 
generally, it opens up a temporal dimension within which intelligent experimentation and continuous improvement at the bottom may compensate for the absence, and indeed in most cases the impossibility, of monolithic functionalist rationalization from above. Accounting in this way for the positive contribution of contested social institutions to economic performance does justice to the Hayekian fact that intelligence in advanced societies is always distributed intelligence, and that social evolution is driven by a diversity of competing forces and interests and cannot be explained by just one of them. Undoubtedly firms and entrepreneurs are very important for the 'variety of capitalism'. Rather than collective enforcers of a coherent institutional design, however, their role is that of creative opportunists that seek advantage in a world inhabited by many others and subservient to many different logics with which they must make their peace if they want prosperity in their time.

The implications of this, I belive, are vast — or may be, depending on how far one is willing to drive the argument. Demonstrations of possibility matter in the social sciences, as the latent capabilities of actors often make as much of a difference in the social world as their manifest actions. But possibility is not necessity. If the possibility of a social constraint on economic action turning out to be economically beneficial depends on a creative entrepreneurial response, whether or not possibility will become into reality is by definition impossible to predict. Certainly theory cannot expect help from those who have to do the trick in practice. At time $t_{1}$, when a constraint is imposed, capitalists will typically claim that it will suffocate the economy, if only because they cannot know yet what they will have learned at time $t_{2}$ that might enable them to live with the new constraint and even utilize it for comparative advantage. ${ }^{3}$ This will be especially the case as new social constraints may favour new firms that may potentially displace their established competitors on account of greater 'fitness' in a politically redefined context.

It follows from this that political resistance to social constraints is not a reliable indicator of their eventual economic effects. On the other hand, not every constraint can be turned around to support economic performance. Social institutions may so limit firms' entrepreneurial choices that even with the best of efforts they cannot find compatible strategic innovations. ${ }^{4}$ Simple bad luck-contingent

\footnotetext{
${ }^{3}$ Put otherwise, capitalist rhetoric will always be one of wholesale social and institutional rationalization, in the same way as it is one of free competition. Both languages, neither of which has much to do with real-world capitalism, capitalists acquire from their favourite writers of uplifting fiction, neo-classical economists, who for good reason make their money not as entrepreneurs but as tenured university professors.

${ }^{4}$ Where this is the case deregulation may be an appropriate strategy in a social market economy such as Germany today. I did not pay sufficient attention to this possibility in my 1993 paper.
} 
failure of a business strategy that might well have worked — may be enough to make excessively costly a regulation introduced into a political economy for political reasons. Also capitalists may refuse even to try to prosper in compliance with institutionalized social demands although they would in principle stand a good chance of succeeding. Later, I shall return to this crucially important possibility.

Before I do this, I will address the second question relevant to our debate, namely whether one can distinguish between higher and lower levels of economic performance in an absolute sense, regardless of the level of profit accruing to capitalist firms. Here, I am in basic agreement with Wright and Tsakalotos. If the performance of a capitalist economy were measured solely in terms of average rates of profit, the early capitalism of the great robber barons would be far superior to the modern capitalism of today. By and large, it appears to be true that average levels of profit have declined with the advance of capitalist modernization, just as Marx and, for different reasons, Schumpeter, have predicted. Can one still say that economic performance has improved over time? And that today's firms perform better than the firms of, say, the late nineteenth century?

A different way of asking the same question takes off from the distinction, common in the American literature, between 'high-road' and 'low-road' business strategies and economic development. In what sense would it be justified to say that an economy performs better if its firms move on the high road, for example competing more on quality than on price and using high-skilled rather than lowskilled labour? Usually the answer refers to benevolent distributional consequences and their positive effects for social cohesion. But if one agreed to leave this aside, could one still maintain that a high-road firm was a better performer than a lowroad firm, even if return on investment was the same or was higher on the low road?

For an answer, consider what standard economic theory has to say about the role of competition. Although it is celebrated as the source of economic progress par excellence, it is, at the same time, extolled for reducing profitability and eventually weeding our profits altogether. This is because competing firms are forced to engage in steady improvement of their operations and capabilities, through technological sophistication, adoption of more advanced methods of accounting and controlling, improved marketing, development of better and more customized products, and so on. Still, overall profitability may remain the same or decline, given that the upgrading of organizational capabilities that is driven by competition sooner or later extends to all firms competing in a given market. Nevertheless, their performance, and with it that of the economy, can be meaningfully said to have improved.

But why should capitalist firms have an interest in improving their performance if this did not translate into higher profits? The reason, I believe, is very simply that 
they have no choice. Indeed, as I shall point out later, it is only if this condition in fact applies that they recognize that interest. Firms capable of high performance respond more effectively to complex task environments. They are better at dealing with change and uncertainty and survive and prosper in more difficult and volatile markets. Squeezed by competition and by consumers with ever more sophisticated tastes, firms are constrained to pursue progressive improvement of their capabilities even though this requires costly investment in capital, managerial effort and entrepreneurial creativity.

There is no reason to believe that firms are necessarily happy with this. Indeed, to the contrary, as Adam Smith noted, wherever capitalists meet, they try to fix prices in order to curtail what they almost inevitably consider 'excessive competition. ${ }^{5}$ Cartels are organized to moderate market pressures for economic progress, while simultaneously lip service is paid to the grand ideal of a competitive market economy. Meanwhile we have come to regard this as normal, just as we have convinced ourselves that it is legitimate for public anti-trust authorities to force firms to continue to upgrade their capabilities, even if they would prefer to do otherwise because improved performance costs them money and profitability is never assured.

In an important sense, the core point of my article on 'Beneficial Constraints' was that the same long-term upgrading of the economic and organizational capabilities of firms that is caused by competitive product markets may also and in basically the same way be caused by social and political regulation. The only difference is that market pressures tend to be regarded as natural whereas social pressures are often seen as additional burdens frivolously imposed on firms that are already about to break down under the pressure of product market competition. But not only are the effects of the two similar, with social constraints forcing firms to become more sophisticated in managing their workforces, upgrade their workers' skills, move from extensive to intensive use of labour, cut down on wasteful consumption of energy, and learn to use more environmentally sustainable production methods. Moreover, if one takes a closer look, the two kinds of pressure, from market and from society, are often hard to distinguish. For example, consumers may join in with governments and buy from producers who minimize the environmental and social costs of their production. In a more general sense, it is in large part democratic redistribution of life chances and wealth that gives rise to the more demanding markets and politics to which competing firms then have to adjust by upgrading and customizing their products.

\footnotetext{
${ }^{5}$ Which implies that Tsakalotos is quite wrong when he locates capitalist interests invariably on the side of deregulation. Correspondingly, the Left for its part cannot be interested in bureaucratic (over-) regulation suffocating entrepreneurship — which even its most radical members recognize by instinct when they go to dinner at a good Tuscan restaurant.
} 
Organizational learning, that is to say, may be initiated, not just by demanding customers, but also by demanding citizens and workers. Social challenges make firms invest in organizational innovations enabling them to cope with turbulent external conditions and handle multiple environments governed by diverse and often incompatible logics. Both evolving markets and an evolving society set in motion a broad process of technical upgrading and social civilization, of the economy as well as of individual and corporate economic actors. In this sense, I agree with Wright and Tsakalotos that there is a general standard of economic performance that is not identical with the rate of profit, and thus with the particularistic performance standards we tend to ascribe to the picture-book capitalist conceived as a simple profit-maximization machine. The final section of my comments will deal with this conception and try to specify the conditions under which it may be more or less realistic.

\section{III}

If interest in profitability is not the same as interest in economic performance, does this imply that profit-maximizing capitalists are inevitably in the way of economic progress, at least beyond a certain point? Here I part company with Wright and Tsakalotos, although with an important qualification: while disagreeing with their general argument, I must admit that under the contingent historical conditions of today's 'globalizing' economy, their empirical intuitions may be quite close to the facts, although for reasons that I feel I can better account for. Wright and Tsakalotos distinguish broadly between constraints that are good for profits and perhaps good for society, and constraints that are good for society and perhaps good for profits but bad for capitalist power-or between constraints favouring capitalists and constraints favouring workers. Whereas capitalists might be willing to submit to the former, they cannot but fight the latter, and to this extent at least social constraints on the economy can have beneficial effects only against capitalist resistance, i.e., probably not. By comparison, I distinguish between constraints that capitalist entrepreneurs learn to use for their advantage, and constraints that stifle their creativity, where importantly it is almost impossible to determine ex ante to which category a given constraint belongs. This I suggest depends, primarily, not on some inherent property of the constraint as such, but on what individual and corporate economic actors manage to make of it-actors that, to complicate things even more, habitually predict doom if they find their freedom of choice reduced to only the slightest extent.

In my article, therefore, all of the constraints whose beneficial effects I discuss are of a sort that capitalists dislike, at least when they are first introduced, such as labour voice at the workplace or strict environmental requirements. After all, what I was trying to demonstrate was precisely that what may initially be, or seem to be, 
a profit-reducing constraint may with time be converted by entrepreneurial ingenuity into a profit-enhancing or at least profit-neutral one. It is this process of conversion by which capitalists learn to redefine their interest in relation to a given institutional arrangement which is at the centre of my concept of beneficial constraint. Whereas Wright and Tsakalotos, the way I read them, exogenize capitalist interests and treat them as fixed, I assume that they are to a theoretically significant extent socially constructed in continuous interaction between capitalists and their society, including the institutions the latter sets up to regulate capitalist economic behaviour.

How do societies educate their capitalists on the substantive content of their interest? Or, in other words, to what social processes are we alerted if we conceive of capitalist interest as a dynamic social construct? What is crucial here is evolution over time. By positing a structure of constraints and opportunities under which individual and corporate economic actors must live and with which they must co-evolve, societies make capitalists develop and deploy their assets so as to fit a social context in which, as a result of their evolving structure, they gradually acquire a 'vested interest'. Like other actors, what emerges from this interaction is a social identity encompassing both normative and strategic components. A firm that has learned to survive as a fair employer or as a quality producer relying on highly skilled labour is likely at some point to identify itself as such, and will subsequently be structurally and culturally averse to redefining itself, even in an economic emergency. In fact it may eventually come to support social regulation to prevent 'social dumping, out of a difficult-to-disentangle mixture of economic interests in limiting competition and cultural commitment that it could abandon only at high cost to both its external reputation and its internal integration. Instead of assuming employers to be capable of convincing themselves in the abstract and on their own of their fundamental economic interest in, say, employment protection or unemployment insurance, ${ }^{6}$ it is much more realistic to model capitalist conversion to welfare state policies as a sequence of productive responses to irremovable social and political constraints.

Socialization of capitalist firms into an economic culture of high performance is neither easy nor assured. Retraining firms to prefer long-term over short-term profitability-which is probably the core discipline of the capitalist educational programme-implies asking them to make efforts that they would rather avoid. Parallels to the socialization of young people are not accidental. Absent certain non-negotiable challenges, potential capabilities may remain underdeveloped, or may not be developed at all. Capitalists, like teenagers, resent having to do what does not come naturally to them, for example save and invest where they would like

\footnotetext{
${ }^{6}$ As does much of the recent revisionist literature on the origins of the welfare state, such as Swenson (2002) in particular.
} 
to consume. Just as liberalism pure and simple is usually not enough to turn a young person into a responsible adult, it probably fails to make a capitalist firm become a high-performance organization. But while the former is by and large accepted, or about to be rediscovered, the latter is far from that, at least in economic doctrine.

My explanation, then, why firms resist attempts by society to socialize them into a culture of high performance is not that they are afraid of losing power, as Wright and Tsakalotos believe. It is rather that they eschew the effort required of them in the course of their re-socialization as 'high-road' producers. To avoid that effort, capitalists opportunistically ask government to protect their product markets and deregulate their labour markets at the same time, both in order to preserve the use value of their capabilities as currently deployed and save themselves from the exertion of developing them further. Firms rationally dislike new constraints, whether from competition or from social intervention, also because they have no way of knowing if in the end they will turn out beneficial for them or not. Whenever they can, they will therefore try to avoid learning, adding to their repertoire only what they must.

Power and class do figure in my 'Durkheimian' concept of the economy, but in ways that differ from Wright and Tsakalotos. 'Worker' power for me is not a result of constraints but their precondition. Of systematic interest for my argument are only those constraints that are imposed by politics on firms against their resistance, if you want, in the pursuit of 'worker' objectives such as 'quality of life' or a fair distribution of life chances. ${ }^{7}$ For the mobilization of the 'power to constrain', the democratic state obviously plays a central role. In other words, by the time capitalists go to work in order to make a virtue out of the political inevitability of social regulation, they have already lost the power that is most important to them: the power to make a fast and easy buck.

On the other hand, by taking power into account, one understands why Wright's and Tsakalotos's pessimism on the extent to which social constraints can have beneficial effects today should appear more realistic than my insistence on the social malleability of the capitalist profit motive. If capitalists are willing to learn only if they cannot avoid it, and otherwise refuse to make the entrepreneurial effort necessary to accommodate social pressures, then the cultural upgrading of capitalist economies is easier inside more or less closed national societies where firms targeted for social re-education have little if any opportunity to exit to more indulgent environments. This is what I say, more or less as an afterthought, in the final paragraph of my article (Streeck, 1997, p. 216). Then, as today, however, my point

\footnotetext{
${ }^{7}$ It goes without saying that workers also need to be educated for their interests to become socially compatible. But this is a different matter, although the mechanisms seem to be similar.
} 
was not, pace Wright and Tsakalotos, that capitalists may emigrate because too many beneficial constraints might curtail their power. Rather, it was that by making it easier for capitalists to leave, globalization, in its today dominant form of liberalization, enhances the power of firms to oppose constraints that they would otherwise have to accommodate through learning. Power, here as elsewhere, amounts to a licence to refuse to learn (Deutsch, 1983). If firms can veto social constraints by threatening relocation to other countries, the mechanism of capitalist re-education for higher performance that I have described and that, I believe, has been centrally important to the evolution of postwar democratic capitalism begins to run dry: still potentially effective, it would increasingly rarely be observed in operation.

Summing up, societies are most likely to succeed in improving their capitalists if they manage to keep them in captivity. Only captive capitalists can become good capitalists-i.e., ones that, under steady prodding from society, overcome their natural inertia and mobilize enough effort to define their special interests in economic performance in such a way that they can be reconciled with general interests in a good economy. That, at least, is my claim in 'Beneficial Constraints'. It goes without saying that such reconciliation can only be precarious as it depends on essentially uncertain and unstable virtuous conjunctures between institutional arrangements, entrepreneurial good luck, and the challenges posed by changing markets and technologies. Moreover, in a world in which capitalism is breaking free from the tutelage of national political systems, alternative mechanisms must be found to provide for its civilization. Whether they exist at all, and what they may look like, is the great question of our time. Can the rational voluntarism of what Hirschman (1992, [1982]) calls doux commerce substitute for the civilizing pressures on capital that were generated in the second half of the twentieth century by national states, governments and social movements? I doubt it.

\section{References}

Deutsch, Karl W. (1963) The Nerves of Government: Models of Political Communication and Control, New York, The Free Press of Glencoe.

Hall, Peter (2003) 'Preference Formation as a Political Process: The Case of European Monetary Union', Minda de Gunzburg Center for European Studies, Harvard University, manuscript.

Hirschman, Albert O. (1992 [1982] ) 'Rival Views of Market Society'. In Rival Views of Market Society and Other Recent Essays, Cambridge, MA, Harvard University Press, pp. 195-241.

Höpner, Martin (2003) Wer beherrscht die Unternehmen? Shareholder Value, Managerherrschaft und Mitbestimmung in Deutschland, Frankfurt/New York, Campus.

Leibenstein, Harvey (1987) Inside the Firm, Cambridge, MA, Harvard University Press. 
Mosher, James S. (2001) Labor Power and Wage Equality: The Politics of Supply-Side Equality, Ph.D. dissertation, University of Wisconsin-Madison, Ann Arbor, MI, UMI Dissertation Services.

Streeck, Wolfgang (1997) 'Beneficial Constraints: On the Economic Limits of Rational Voluntarism'. In Hollingsworth, J. Rogers and Boyer, Robert (eds) Contemporary Capitalism: The Embeddedness of Institutions, Cambridge: Cambridge University Press, pp. 197-218.

Swenson, Peter A. (2002) Capitalists against Markets: The Making of Labor Markets and Welfare States in the United States and Sweden, Oxford: Oxford University Press. 